\title{
The effect of different types of window for residential building based on intermittent heating supply
}

\author{
Chenyang $\mathrm{Tao}^{1}$, Nan $\mathrm{Li}^{1}$ and Yuchen Wang ${ }^{2}$ \\ ${ }^{1}$ National Centre for International Research of Low-carbon and Green Buildings, Ministry of Science \& Technology, Chongqing \\ University, Chongqing 400045, China \\ ${ }^{2}$ Schneider Electric (China) Co., Ltd. Shanghai Branch, Shanghai, 200233, China
}

\begin{abstract}
Aiming to lessen energy consumption and heating cost, this paper analyzes the effect of different types of window for residential building based on intermittent heating supply. The research results show that the type of window with a smaller heat transfer coefficient has higher energy consumption. Otherwise, the rate of temperature rising is slightly affected by the change of window with different heat transfer coefficient and window-to-wall ratio. Based on the economic and technical analysis, through changing the better window, energy-saving ratio can be arrived to $10.4 \%-16.8 \%$ and economic recovery period is $4.4-10.4$ years. The research findings can be used for reference to thermal design in new residential buildings and provide improvement of building performance for existing residential buildings.
\end{abstract}

\section{Introduction}

In the hot summer and cold winter areas of China, the heat loss of the residential building envelope structure accounts for $70 \%-80 \%$ of the total heat loss, and the total heat loss of the window accounts for $47 \%$ of the total heat loss. Therefore, the energy-saving renovation of windows plays an important role. Ricardo M.S.F. Almeida et al. [1] revealed that the windows' permeability indices ranged from 4.8 to $96.4 \mathrm{~m}^{3} /\left(\mathrm{h} \cdot \mathrm{m}^{2}\right)$ and from 1.2 to $30.8 \mathrm{~m}^{3} /\left(\mathrm{h} \cdot \mathrm{m}^{2}\right)$, with average values of $28.7 \mathrm{~m} /\left(\mathrm{h} \cdot \mathrm{m}^{2}\right)$ and $8.9 \mathrm{~m} /\left(\mathrm{h} \cdot \mathrm{m}^{2}\right)$, the roller-shutter contribution can be highly variable; also the year of construction, the frame material and the opening system are the key parameters for the airtightness of windows in Southern European. Otherwise, based on the intermittent heating supply system which is generally believed that can significantly reduce the heating energy consumption and cost compared with the continuous heating [2-5]. The article tries to reveal the influence of different types of window for the energy consumption of residential building in Chongqing.

\section{The Simulation Model}

The simulation model is established by DesignBuilder, aiming to make a research about the effect of windows for intermittent heating energy, which is an existing residential building in Chongqing. And in details, the experiment platform (ROOM1) is the bedroom with a total area of 7.6 square meters and 3.5 meters floor height. The single housing model are shown as Fig.1.

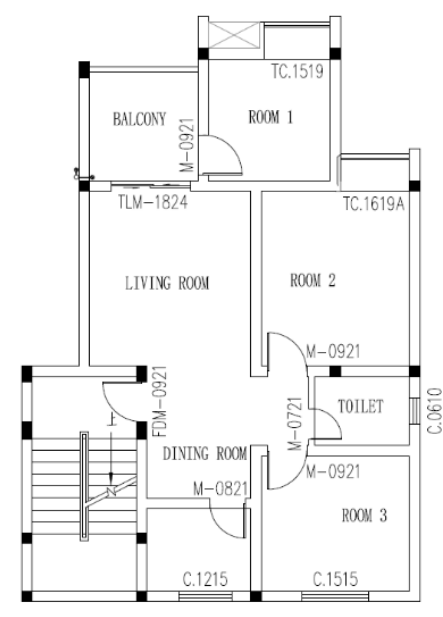

Fig. 1 Experimental building plan

The other building envelope parameters in Chongqing are showed as follows:

Table 1 Building envelope parameters in Chongqing

\begin{tabular}{|c|c|c|}
\hline Type & $\begin{array}{c}\text { Heat transfer } \\
\text { coefficient } \\
\left(\mathrm{W} / \mathrm{m}^{2} \cdot \mathrm{K}\right)\end{array}$ & $\begin{array}{c}\text { Thermal } \\
\text { resistance } \\
\left(\mathrm{m}^{2} \mathrm{~K} / \mathrm{W}\right)\end{array}$ \\
\hline External wall & 1.31 & 0.763 \\
\hline Internal wall & 1.46 & 0.685 \\
\hline Floor & 2.92 & 0.342 \\
\hline Door & 2.47 & 0.405 \\
\hline Window & 2.80 & 0.357 \\
\hline
\end{tabular}

The real-time data of an experimental day in January, based on the indoor temperature set-point $20^{\circ} \mathrm{C}$ and the operation time from 17:00PM to 8:00AM, are used to 
make the model's accuracy test. The result of simulating is showed as Table. 2 .

Table 2 Statistics of simulation

\begin{tabular}{|c|c|c|c|}
\hline Situation & $\begin{array}{c}\text { Fast } \\
\text { response } \\
\text { rate }\left({ }^{\circ} \mathrm{C} / \mathrm{h}\right)\end{array}$ & $\begin{array}{c}\text { Average } \\
\text { attenuation } \\
\text { rate }\left({ }^{\circ} \mathrm{C} / \mathrm{h}\right)\end{array}$ & $\begin{array}{c}\text { Daily energy } \\
\text { consumption } \\
(\mathrm{kW} \cdot \mathrm{h})\end{array}$ \\
\hline Simulation & 3.3 & 0.7 & 11.59 \\
\hline Experiment & 3.0 & 0.6 & 10.71 \\
\hline
\end{tabular}

From the simulation results, the energy consumption value is $11.59 \mathrm{k} \mathrm{kW} \cdot \mathrm{h}$, which is about $8.2 \%$ different from the measured energy consumption data. So, the simulation model is relatively credible.

\section{Result Analysis}

\subsection{The window's type and window-to-wall ratio}

5 different windows with equal spacing between $20 \%$ and $60 \%$ of window-wall ratio( $\mathrm{R})$ is to be simulated. The type and heat transfer coefficient $(\mathrm{K})$ of window are as follows.

Table 3 Parameters of Windows

\begin{tabular}{|c|c|c|c|}
\hline NO. & Type & $\begin{array}{c}\text { Heat transfer } \\
\text { coefficient } \\
\left(\mathrm{W} / \mathrm{m}^{2} \cdot \mathrm{K}\right)\end{array}$ & Composition \\
\hline 1 & Single & 5.7 & $3 \mathrm{~mm}$ CLR \\
\hline 2 & Single-low-e & 4.5 & $\begin{array}{c}3 \mathrm{~mm} \text { Low-E } \\
\text { CLR(e=4) }\end{array}$ \\
\hline 3 & Single-low-e & 3.6 & $\begin{array}{c}6 \mathrm{~mm} \text { Low-E } \\
\text { CLR }(\mathrm{e}=2)\end{array}$ \\
\hline 4 & Double- low-e & 2.8 & $3+6 \mathrm{~A}+3$ \\
\hline 5 & Double- low-e & 1.7 & $3+13 \mathrm{~A}+3$ \\
\hline
\end{tabular}

The difference of room rapid response rate, room temperature and energy consumption in the stable stage are contrasted by simulation.

\subsection{Effect of window on energy consumption of heating rooms in winter}

According to the regulations, the total energy consumption of the residential is simulated for 88 days from December 1 to February 28 in winter. The following Fig. 2 shows the effects on types of window.

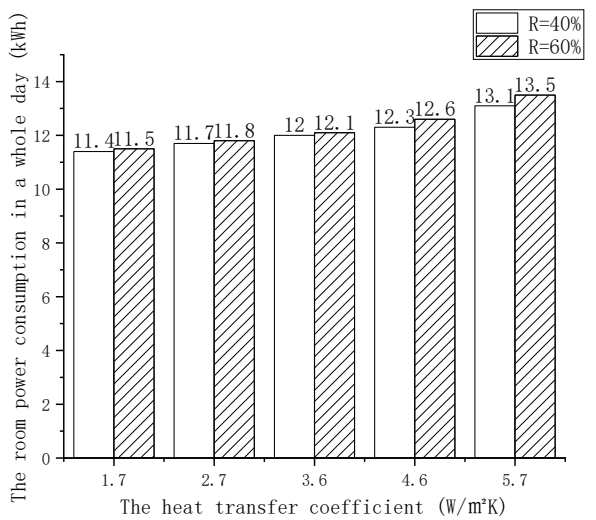

Fig. 2 The effects on energy consumption
As the $\mathrm{K}$ of the window increases, the building heating energy consumption increases, and this trend becomes more and more significant with the increase of the window-to-wall ratio. When the window-to-wall ratio is $40 \%$, and the $\mathrm{K}$ value is $1.7 \mathrm{~W} / \mathrm{m}^{2} \mathrm{~K}$, the building energy savings is $13.0 \%$ and the elastic coefficient is $18.6 \%$. When the window-to-wall ratio is $60 \%$, the energy savings is $14.8 \%$ and the elastic coefficient is $21.1 \%$.

The $\mathrm{K}$ of the window has a significant impact on the energy consumption of the room. The $\mathrm{R}$ is a characteristic factor of the heat transfer area of the window. The change of the $\mathrm{R}$ affects the winter heat load of the room, which affects the annual energy consumption of the residential building and the indoor room temperature.

From the Fig.3, the increase in the energy consumption of the single-day heating of the room increases with the R, but as the value of $\mathrm{K}$ decreases, the change in the power consumption caused by the $\mathrm{R}$ is weakened. When the $\mathrm{K}$ value is 5.7 , the $60 \% \mathrm{R}$ energy consumption is 1.08 times that of $20 \%$, and the energy saving is only $7.5 \%$ and the elastic coefficient is $11.4 \%$. When $\mathrm{K}$ is 3.6 , the $60 \% \mathrm{R}$ energy consumption is 1.04 times that of $20 \%$ and the elastic coefficient is $6.2 \%$. The influence of the $\mathrm{R}$ on energy consumption is lower than the influence of the $\mathrm{K}$ of the window.

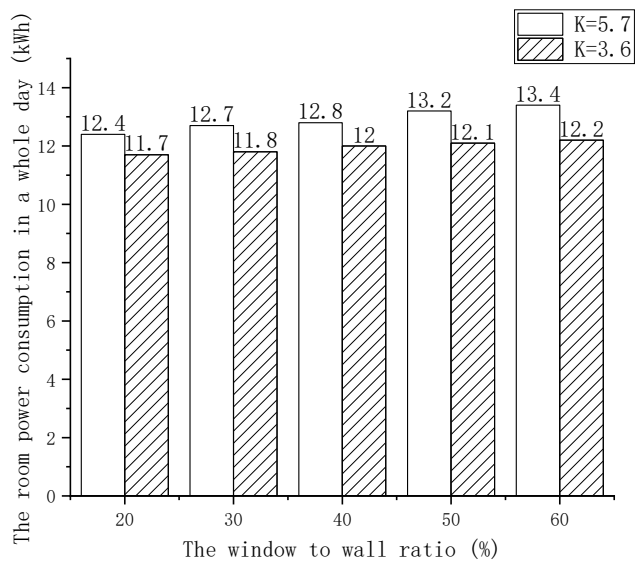

Fig. 3 The effects on energy consumption

\subsection{Annual energy consumption and operating cost}

In order to comprehensively consider the $\mathrm{K}$ of the window, the $\mathrm{R}$ and other factors, the total annual energy consumption is simulated. The simulated indoor temperature is $26^{\circ} \mathrm{C}$, and the energy consumption is simulated by $\mathrm{COP}=2.8$. The power consumption of the single-day room in the whole year is shown in the Fig.4. 


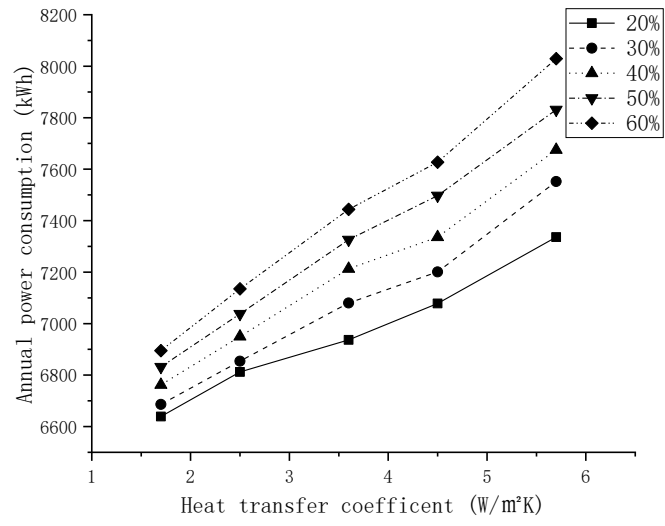

Fig. 4 Annual energy consumption

According to the results, the annual electricity consumption is linear with the $\mathrm{K}$. As the $\mathrm{R}$ increases, the intercept increases and the slope increases slightly.

In the case of the same $\mathrm{R}$, the energy saving rate of the $\mathrm{K}$ of different windows is shown in the following Table 4.

Table 4 Economy energy rates

\begin{tabular}{|c|c|c|c|c|c|}
\hline $\begin{array}{c}\text { Window-to- } \\
\text { wall rate (\%) }\end{array}$ & 20 & 30 & 40 & 50 & 60 \\
\hline $\begin{array}{c}\text { Energy saving } \\
\text { rate (\%) }\end{array}$ & 10.44 & 12.44 & 13.02 & 15.53 & 16.79 \\
\hline
\end{tabular}

*the energy saving rates are calculated under the comparison between $\mathrm{K}=1.7 \mathrm{~W} / \mathrm{m}^{2} \cdot \mathrm{K}$ and $\mathrm{K}=5.7 \mathrm{~W} / \mathrm{m}^{2} \cdot \mathrm{K}$.

Overall, the total annual energy consumption increases with the increase of the window heat transfer coefficient, and increases with the increase of the window to wall ratio.

The electricity price in Chongqing is calculated as 0.57 yuan/KWh. Window cost is shown in the Table 5.

Table 5 Cost of windows

\begin{tabular}{|c|c|c|c|c|}
\hline No. & Type & $\begin{array}{c}\mathrm{K} \\
\left(\mathrm{W} / \mathrm{m}^{2} \cdot \mathrm{K}\right)\end{array}$ & $\begin{array}{c}\text { Cost of } \\
\text { glass } \\
\left(\text { yuan } / \mathrm{m}^{2}\right)\end{array}$ & $\begin{array}{c}\text { Cost of } \\
\text { windows } \\
\left(\text { yuan } / \mathrm{m}^{2}\right)\end{array}$ \\
\hline 1 & Single & 5.7 & 45 & 139 \\
\hline 2 & $\begin{array}{c}\text { Single- } \\
\text { low-e }\end{array}$ & 4.5 & 69 & 256 \\
\hline 3 & $\begin{array}{c}\text { Single- } \\
\text { low-e }\end{array}$ & 3.6 & 99 & 360 \\
\hline 4 & $\begin{array}{c}\text { Double- } \\
\text { low-e }\end{array}$ & 2.8 & 139 & 497 \\
\hline 5 & $\begin{array}{c}\text { Double- } \\
\text { low-e }\end{array}$ & 1.7 & 204 & 689 \\
\hline
\end{tabular}

The electricity fees in different $\mathrm{K}$ and $\mathrm{R}$ are shown in the Fig.5.

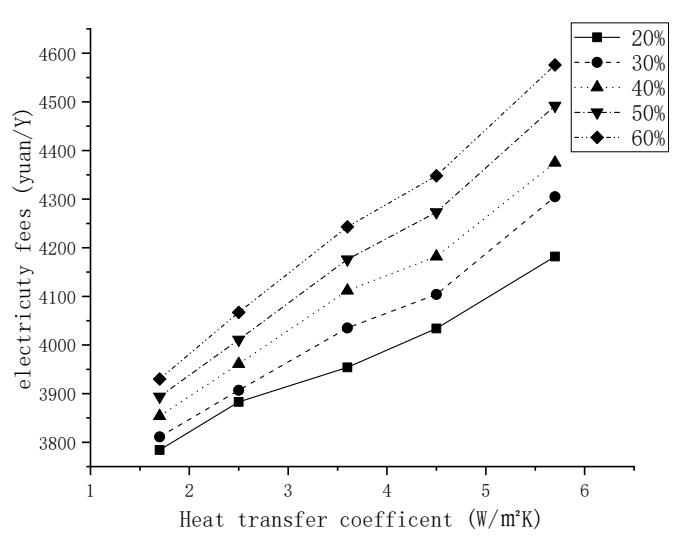

Fig. 5 Annual operating cost

Considering the service life of the equipment is 10 years, the corresponding static investment payback period in each case is calculated, as shown in the following Fig.6.

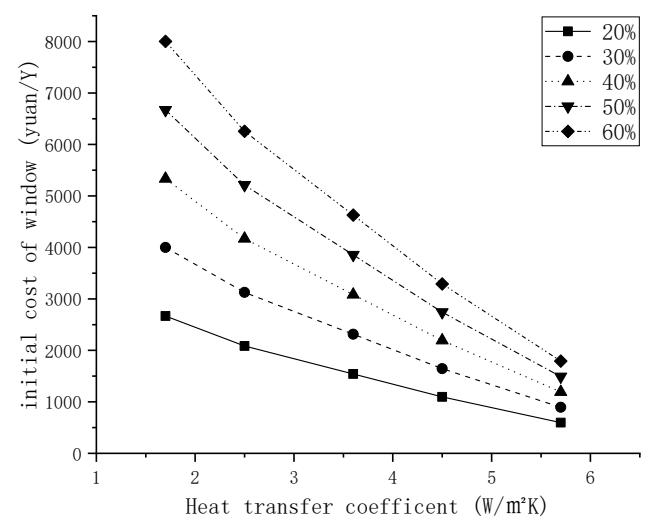

Fig. 6 Initial cost of energy-saving transformation

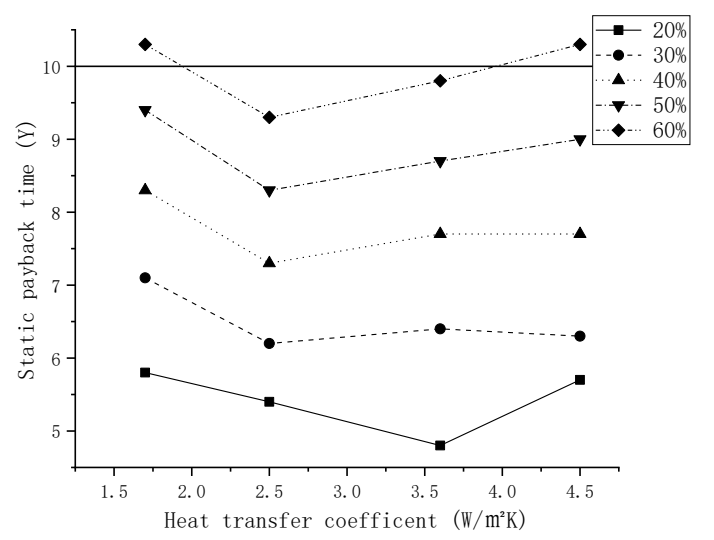

Fig. 7 Static payback time

According to the results of simulation about the effect of window-to-wall rate and window heat transfer coefficient on energy consumption, the benchmark investment payback period is determined based on the service life of the air source heat pump equipment for 10 years. As can be seen from the above Fig.7, when the $\mathrm{R}$ is $60 \%$ or more, considering the benchmark investment recovery period value of 10 years, it is reasonable to change the thermal parameters of the window in the range of 2.0-3.9 W/( $\left.\mathrm{m}^{2} \cdot \mathrm{K}\right)$. Outside of this range, costs cannot 
be recovered within the specified time.

When the $\mathrm{R}$ is $50 \%$, it is recommended to adjust the $\mathrm{K}$ of the window to be higher than $2.0 \mathrm{~W} /\left(\mathrm{m}^{2} \cdot \mathrm{K}\right)$ during energy-saving retrofit.

When the $\mathrm{R}$ is between $30 \%$ and $50 \%$, it is recommended to set the $\mathrm{K}$ value within the range of 2.4$3.0 \mathrm{~W} /\left(\mathrm{m}^{2} \cdot \mathrm{K}\right)$, and the investment recovery period has obvious advantages.

When the $\mathrm{R}$ is $20 \%$, the investment payback period is the shortest, when $\mathrm{K}$ is $3.6 \mathrm{~W} /\left(\mathrm{m}^{2} \cdot \mathrm{K}\right)$, and is the lowest of the various cases occurring in the simulation -4.8 years.

In particular, when the $\mathrm{R}$ is $30 \%$ and the $\mathrm{K}$ is greater than $2.0 \mathrm{~W} /\left(\mathrm{m}^{2} \cdot \mathrm{K}\right)$, the investment payback period of the window fluctuates significantly.

In general, when $\mathrm{K}$ is lower than $2.0 \mathrm{~W} /\left(\mathrm{m}^{2} \cdot \mathrm{K}\right)$, the investment recovery period is longer than that under the same R. Therefore, it is not recommended to select the heat transfer coefficient of the window to $2.0 \mathrm{~W} /\left(\mathrm{m}^{2} \cdot \mathrm{K}\right)$ or less during energy-saving renovation, and the smaller the window to wall ratio, the shorter the payback period required.

As mentioned in the previous article, in the case of fixed window-to-wall ratio and temporarily not considering the relevant provisions of energy-saving design specifications for hot summer and cold winter regions, considering the window heat transfer coefficient and investment recovery period, suggestions for engineering significance are proposed.

Table 7 Recommendation of windows

\begin{tabular}{|c|c|c|c|}
\hline $\begin{array}{c}\text { Window-to-wall } \\
\text { rate }\end{array}$ & $<20 \%$ & $20 \%-60 \%$ & $>60 \%$ \\
\hline Recommended K & Near 3.6 & Near 2.7 & $\begin{array}{c}2.7 \text { or as } \\
\text { the origin }\end{array}$ \\
\hline
\end{tabular}

\section{Conclusion}

- The effect of window-to-wall rate on energy consumption is less than the effect of window heat transfer coefficient.

- Under the pattern of intermittent heating supply, by changing the better window, energy-saving ratio can be arrived to $10.4 \%-16.8 \%$ and economic recovery period is 4.4-10.4 years.

- Based on the results of economic and technical analysis, recommendation of windows used to save energy consumption is proposed.

\section{Acknowledgements}

The study has been supported by the China National Key R\&D Program (Grant No. 2018YFC0705206) and International Science \& Technology Cooperation Program of China (Grant No. 2014DFA62970).

\section{References}

1. Ricardo M.S.F. Almeidaa, Nuno M.M. Ramos, Pedro F. Pereira, 139(2017)174-185

2. Badran, A. A., Jaradat, A. W., \& Bahbouh, M. N.
Energy Conversion and Management, 65, 709714(2015)

3. Barrios, G., Huelsz, G., \& Rojas, J. Applied Thermal Engineering, 40, 1-7 (2012)

4. Behzadi, S., \& Farid, M. M.HVAC \& R Research, 17(3), 366-376(2011)

5. Castell, A., Martorell, I., Medrano, M. Pérez, G., \& Cabeza, L. F. Energy and Buildings, 42, 534$540(2010)$ 